\title{
RZEKOMY EKSLIBRIS NOWEJ BIBLIOTEKI KSIĘCIA ALBRECHTA PRUSKIEGO
}

W zbiorach Biblioteki Uniwersyteckiej w Toruniu zachowały się w pewnej liczbie ksiażki ze zbiorów dawnej Biblioteki Państwowej i Uniwersyteckiej w Królewcu. Wśród nich znajdują się książki pochodzące z tzw. Nowej Biblioteki ${ }^{1}$ (Nova Bibliotheca) nazywanej także biblioteką zamkową. Założył ją w 1529 roku pierwszy świecki władca Prus Książęcych, książę Albrecht, jako bibliotekę zamkową przeznaczoną dla środowiska naukowego Królewca.

Książki z tego księgozbioru jest łatwo zidentyfikować ${ }^{2}$, ponieważ wiele z nich jest zaopatrzonych w ekslibris występujący w kilku odmianach. Ich pełną klasyfikację dał Arthur Warda ${ }^{3}$, dzieląc je na trzy grupy, w obrębie których wyróżnił 9 wariantów.

Wśród zachowanych w Toruniu woluminów z tej biblioteki najbardziej popularny jest wariant mieszczący się w grupie III. Jak wszystkie, składa się z trzech części: nadpisu ograniczającego się do tytulatury fundatora Nowej Biblioteki, herbu władcy pruskiego oraz podpisu adresowanego „Ad lectorem”. Większa jego popularność jest zrozumiała, ponieważ był on naklejony na ksiażki formatu octavo, których z Nowej Biblioteki zachowało się najwięcej.

Tylko w jednym egzemplarzu natomiast występuje quasi-ekslibris Nowej Biblioteki. I właśnie on nasuwa kilka przypuszczeń, które chcemy w niniejszym przyczynku przedstawić. Zanim to jednak uczynimy, najpierw kilka informacji wstępnych.

Quasi-ekslibris jest przyklejony na wyklejce górnej okładki woluminu (Inc.IV, 1) zawierającego „Kölnische Chronick" (Köln, J. Koethoff, 1499, $2^{\circ}$ ), dzieła bardzo popularnego $w X V$ wieku ${ }^{4}$, a chętnie także czytanego $w X V I$ w., o czym świadczą ślady intensywnej lektury zachowane na toruńskim egzemplarzu. Sam blok książki jest dobrze zachowany. $Z$ zestawienia zawartości dzieła $z$ opisem umieszczonym w "Gesamtkatalog der Wiegendrucke ${ }^{5}$ wynika, iż toruński egzemplarz jest wariantem ze zmianami tekstu wprowadzonymi $w$ trakcie tłoczenia nakładu, oraz że brakuje początkowych 14 kart. Książka liczy 354 karty miast 368 . Kart tych już nie było $w$ chwili zaopatrywania inkunabułu w oprawę. Oprawa składa się z desek pokrytych białą, teraz pożółkłą świńską skórą i jest zdobiona, pomijając dwa małe thoki, dwoma radełkami. Jedno radełko zawiera głowy czterech reformatorów ujęte w medaliony z napisami: MARTI[nus] LVTHE[rus] - PHILIP:[us] MELAN[thon] JOANNES HVS 1415 - ERASMVS ROT[e]RODA[mus]. Drugie zaś radełko, składające się także z czterech elementów, przedstawia: 1) putto z oszczepem, obok którego widnieje herb, 2) putto grające na bębnie, 3) putto napinające łuk i herb 
saski z rutą, 4) dziewczynę z rozwianymi włosami, z odciśniętymi obok jej głowy literami H.H. Radełkami tymi wykonano ramki tak na górnej, jak i dolnej okładce.

Badania Kuhnerta nad introligatorstwem królewieckim wykazuja, iż oba radeł$\mathrm{ka}^{6}$ należały do Kaspra Anglera, najwybitniejszego introligatora XVI wieku, pozostającego na usługach dworu książęcego przez 32 lata (1533-1564). Oprawiał on książki przede wszystkim do zbiorów Nowej Biblioteki, używając do ich dekoracji, jak wskazują zachowane w zbiorach Biblioteki Uniwersyteckiej woluminy, najczęściej właśnie owych dwóch radełek.

Interesujący nas egzemplarz oprawiał Angler w latach 1564-1565. Możemy tak zakładać, ponieważ brakuje na nim tak sygnatury Feliksa Königa Polyphema ${ }^{7}$, pierwszego bibliotekarza Nowej Biblioteki (1534-1549), jak i Henryka Zella (15571564); inni bibliotekarze królewieccy nie podejmowali tak mało efektywnego zajęcia, jakim było sygnowanie. Widnieje natomiast na grzbiecie oprawy sygnatura oraz mało starannie wypisany tytuł, w sposób właściwy dla następcy Zella, Jana Steinbacha $^{8}$ (1564-1566).

W tym samym czasie naklejony został ów interesujący nas pseudoekslibris. Jego szerokość wynosi $121 \mathrm{~mm}$, drugi pełny wymiar nie jest nam znany, ponieważ dolna partia pseudoekslibrisu została obcięta. W obecnej postaci składa się z dwóch części: z 6 wierszowego napisu w języku niemieckim: Von Gottes Gnaden $\mathrm{Al} /$ brecht der Eltern Marggraff zu Brandenburg / inn Preussen zu Stetin, Pommern, der / Cassuben, und Wenden Herztzog, Burg/graff zu Nürnberg, und Fürst zu Rügen, etc. i z herbu o wymiarach $140 \mathrm{~mm} \times 100 \mathrm{~mm}$.

Na obciętym fragmencie quasi-ekslibrisu, znajdował się zapewne wytloczony rok „1559”, jaki figurował na innych znanych jego egzemplarzach ${ }^{9}$, pochodzacych wyłącznie z tomów zawierających druk „Kirchenordnung" drukowany w 1558 roku przez królewieckiego typografa Hansa Daubmanna. Rok 1559 był rokiem publikacji "Kirchenordnung". Ów quasi-ekslibris miał, jak się słusznie przypuszcza ${ }^{10}$, wzmocnić rangę owego "Kirchenordnung”. Tym bardziej ta opinia wydaje się prawdopodobną, gdy weźmiemy pod uwagę fakt, że wprowadzony z pominięciem Stanów spotkał się z ostrym sprzeciwem szlachty. Sprawując patronat nad kościołami wywierała ona presję na duchowieństwo, aby nie respektowało nowego „Porządku". Czyniła to nienadaremnie. Praktyka naklejania quasi-ekslibrisu na egzemplarzu „Kirchenordnung” z 1558 nie dała oczekiwanego przez wadzę rezultatu. W 1566 roku przywrócono w kościele pruskim wcześniejszy „Porządek Kościelny” z 1544 roku $^{11}$.

Omawiany jego toruński egzemplarz jest jedynym znanym, jaki został naklejony na inny druk niż „Kirchenordnung " z 1558 roku. „Amputowany" o fragment z datą - 1559 - pełnił funkcję znaku własnościowego potwierdzającego to, co już ustaliliśmy w oparciu o dekorację oprawy oraz naniesione na jej grzbiecie napisy, iż przechowywany obecnie w zasobie starych druków Biblioteki Uniwersyteckiej w Toruniu inkunabuł - „Kölnische Chronick” pochodzi ze zbiorów Nowej Biblioteki.

Ten quasi-ekslibris rodzi pytanie o jego związki z ekslibrisem Nowej Biblioteki. Otóż wydaje się, iż ekslibris był na nim wzorowany. Wprawdzie teoretycznie, ekslibris thoczony przez wspomnianego Hansa Daubmanna, mógł już powstać w 1544 roku, w którym ten największy królewiecki impresor uruchomił swój war- 
sztat $^{12}$, ale w rzeczywistości jest to mało prawdopodobne. W pierwszych bowiem latach działalności Daubmanna nad Pregoła, sprawujący wówczas funkcję bibliotekarza (1553-1556) Dawid Milesius, pochłonięty praktyką lekarską oraz twórczością poetycką - określał siebie jako „poeta laureatus" - nie interesował się sprawami bibliotekarskimi. Biblioteka w okresie jego rą̧dów znajdowała się w impasie, powiększała swoje zbiory znacznie wolniej, niż za jego poprzedników - Marcina Chemnitza, a zwłaszcza Polyphema. Trudno byłoby więc łączyć osobę Milesiusa, rażąco zaniedbującego kierowaną przez siebie bibliotekę, z genezą ekslibrisu Nowej Biblioteki ${ }^{13}$.

Znacznie bardziej prawdopodobne jest założenie, iż autorem pomysłu zaopatrzenia książek biblioteki zamkowej w ekslibris był Henryk Zell, który obowiązi bibliotekarza podjałł, jak już ws pomnieliśmy w 1557 roku i pełnił je do przedwczesnej śmierci w 1564 roku. W matrykułach ${ }^{14}$ Akademii Królewieckiej figuruje on jako "mathematicus excellens et cosmographus"15. Określenia te nie w pełni oddaja jego aktywność naukową i zawodową. Był bowiem przed przybyciem do Królewca także drukarzem. Jego aktywność na tym polu jest zrozumiała, pochodził bowiem ze znanej rodziny kolońskich typografów: jego dziadek Ulrich Zell był pierwszym impresorem Coloniaae Agripinensis. Zajmował się także historią. Napisał poświęcone księciu Albrechtowi dzieło genealogiczne wytłoczone przez Daubmanna w 1563 roku.

Najlepsze wyniki osiagnął w pracy bibliotekarskiej. Wyliczmy jego osiągnięcia na tym polu ${ }^{16}$. Otóż rocznie przeciętnie zakupywał książek za kwotę 5,5 raza większą niż Milesius (270 grzywien), co w zestawieniu z aktywnością jego poprzedników w tej dziedzinie ma swoją wymowę. Znalazł również czas na opracowanie zbiorów $^{17}$, czego bardzo niechętnie podejmowali się XVI-wieczni bibliotekarze; sporządził katalog. Książki zaopatrywał w sygnatury, których wcześniej nie posiadały, za wyjątkiem inkunabułów i rękopisów. Umieszczał je na górnym marginesie karty tytułowej oraz na grzbiecie ksiażki. Ze względu na to, iż sygnatury pisane czarnym tuszem na brązowej skórze były mało czytelne, wprowadził w miejsce dotychczas stosowanej przez introligatorów królewieckich skóry cielęcej-świńską. Jej biała barwa była optymalnym tłem dla sygnatur, jak również tytułów kaligraficznie przez niego wypisywanych na grzbiecie oprawy.

W świetle tych dokonań Zella, jakie mogły być udziałem jedynie „urodzonego bibliotekarza", nasza supozycja, iż jego oddaniu bibliotece oraz inwencji zawdzięczała ona ekslibris, jest bardzo prawdopodobna. Niewykluczone nawet, iż rzekomy ekslibris był jego oryginalnym pomysłem, aczkolwiek nie mamy na to wystarczająco przekonywujących argumentów.

\section{Przypisy}

' E. Kuhnert, Die Nova Bibliotheca des Herzogs Albrecht, [W:] Festschrift fūr Franz Milkau, Leipzig 1921, s. 210-218; tegoż: Geschichte der Staats - und Universitätsbibliothek zu Königsberg. Von ihrer Begründung bis zum Jahre 1810, Leipzig 1926, s. 14-68.

\footnotetext{
2 J. Tondel, Das Schicksal der Königsberger Schlossbibliothek, Preussenland Jg.25, 1987, Nr 2/3, s. 39-48.
} 
${ }^{3}$ A. Warda, Die Exlibris des Herzogs Albrecht von Preussen, [W:] Königsberger Beiträge. Festgabe zur Vierhundertjāhrigen Jubelfeier der Staats- und Universitätsbibliothek zu Königsberg Pr., Königsberg Pr. 1929, s. 349-354.

${ }^{4}$ S. Corsten, Die Kölnische Chronick von 1499, Hamburg 1982.

${ }^{5}$ Gesamtkatalog der Wiegendrucke. Hrsg. von der Kommision für den Gesamtkatalog der Wiegendrucke. Bd. 6. 2. Aufl. Stuttgart, New York, 1968, nr 6688; Zob. także: Incunabula quae in bibliothecis Poloniae asservantur. Moderante A. Kawecka-Gryczowa, composuerunt M. Bohonos et E. Szandorowska. T. 1. Wratislaviae 1970, nr 1519; St. Lisowski, Inkunabuly Biblioteki Uniwersyteckiej w Toruniu, Zeszyty Naukowe Uniwersytetu M. Kopernika w Toruniu. Nauki Humanistyczno-Spoleczne Z. 11. Nauka o ksiażce II, Toruń 1964, s. 152, nr 43.

${ }^{6}$ E. Kuhnert, Der Kōnigsberger Bucheinband im XVI und XVII Jahrhundert, [W:] tegoż: Geschichte, s. 276, 273; K. Haebler, Rollen- und Platteństempel des XVI Jhd. Bd. 1, Leipzig 1928, s. 14, nr 24; 2.

7 J. Tondel, Rękopiśmienne katalogi królewieckiej biblioteki zamkowej z lat 1540-1548 autorstwa Feliksa Königa Polyphema. Ze Zbiorów Biblioteki Uniwersyteckiej w Toruniu [W:] Studia o bibliotekach i zbiorach polskich. Pod red. B. Ryszewskiego, t. 1, Toruń, 1991, s. 7-18.

${ }^{8}$ O działalności bibliotekarskiej kolejnych kierowników Nowej Biblioteki w czasach rządów Albrechta zob. E. Kuhnert, Geschichte, s. 14-68, passim.

${ }^{9}$ A. Warda, op. cit., s. 349, 353-354.

${ }^{10}$ Tamże, s. 354.

${ }^{11}$ W. Hubatsch, Geschichte der evangelischen Kirche Ostpreussens. Bd. 1. Göttingen 1968, 5.490.

${ }^{12}$ Drukarze dawnej Polski od XV do XVIII wieku. Red. A. Kawecka-Gryczowa. T. 4. Pomorze. Oprac. A. Kawecka-Gryczowa, K. Korotajowa, Wroctaw, s. 70-71.

${ }^{13}$ E. Kuhnert, Geschichte, s. 49-50.

${ }^{14}$ S. Erler, Die Matrikel der Albertus-Universitäts zu Königsberg Pr. Bd. 1, Leipzig 1910, s. 19.

15 KH. Burmeister, Der Kartograph Heinrich Zell (1518-1564), [W:] Science and history, Wrockaw 1978, s. 427-442, Stucia Copernicana 16.

${ }^{16}$ A. Kolb, Der Kartograph Heinrich Zell, ein unbekannten Strasburger Drucker des 16 Jahrhunderts, „Gutenberg Jahrbuch" 47, 1972, s. 174-177.

${ }^{17}$ E. Kuhnert, Heinrich Zell, [W:] Beiträge zum Bibliotheks und Buchwesen Paul Schwenke gewidmet, Berlin 1913, s. 137-147, zob. tegoż: Geschichte, s. 50-60. 


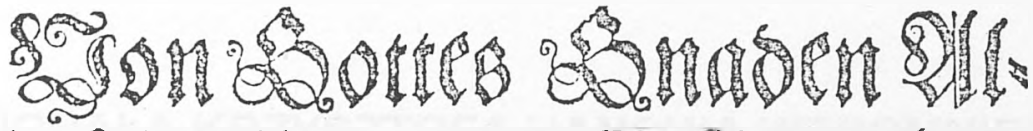

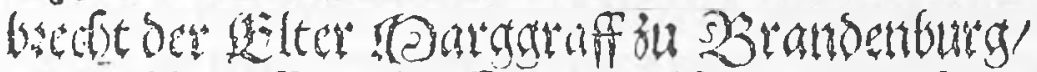

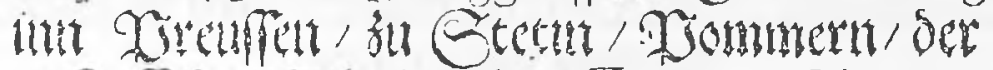

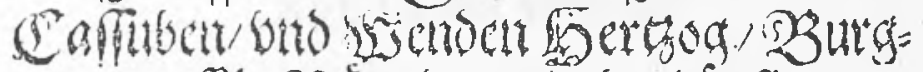

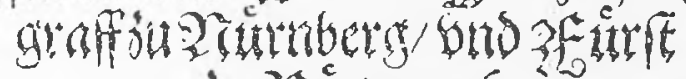

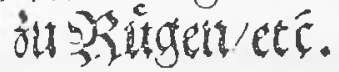

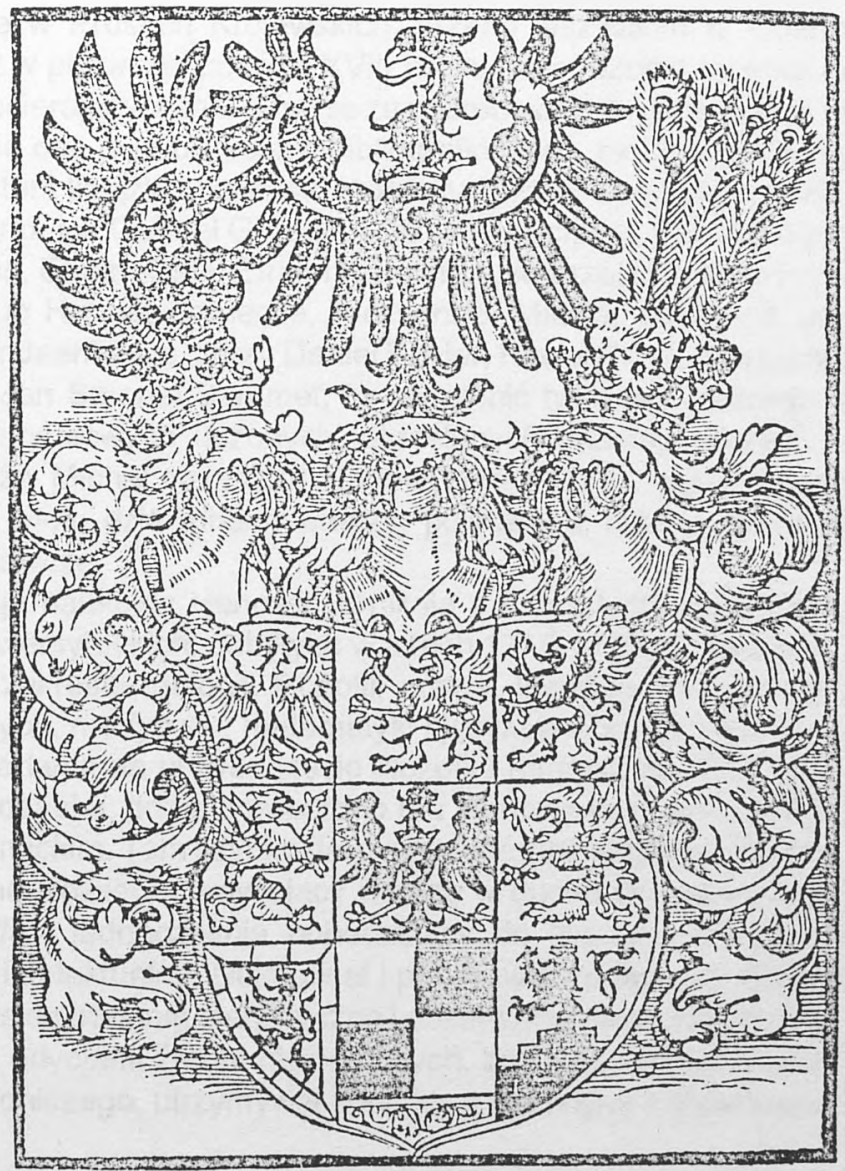

„Rzekomy ekslibris Nowej Biblioteki Księcia Albrechta Pruskiego". Biblioteka Uniwersytecka w Toruniu, sygn. Inc. IV. 1. 